\title{
Resolución judicial y extrajurisdiccional de conflictos en el proceso de modernización de la Administración de Justicia
}

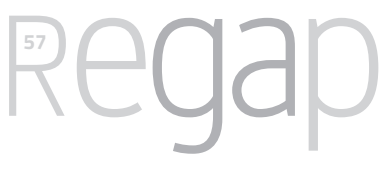

\author{
ALMUDENA VALIÑO CES \\ Profesora de Dereito Procesual \\ Universidade de Santiago de Compostela \\ almudena.valino@usc.es
}

Recibido: 21/06/2019| Aceptado: 18/07/2019

DOI: https://doi.org/10.36402/regap.v1i57.12

MÍGUEZ MACHO, L., e GONZÁLEZ MORENO, B. (coords.):Resolución judicial y extrajurisdiccional de conflictos en el proceso de modernización de la Administración de Justicia, Tirant lo Blanch, Valencia, 2017, 358 pp. ISBN: 978-84-9143-677-5.

Esta obra colectiva, coordinada polos profesores Míguez Macho e González Moreno, é o resultado de dous seminarios organizados pola Asociación Interdisciplinaria de Dereito Público, pois constitúen foros para o debate científico acerca de cuestións relevantes para o dereito público por parte de investigadores e profesionais pertencentes a diferentes áreas de coñecemento. Nela analízase, ao longo das súas dúas partes, un conxunto de reflexións de profesores universitarios e maxistrados sobre a resolución xudicial e extraxurisdicional de conflitos no marco do proceso de modernización da Administración de xustiza. En concreto, na primeira delas estúdase a resolución xudicial e extraxurisdicional de conflitos e na segunda abórdase a situación pasada e presente da Administración de xustiza cara a unha modernización necesaria.

Desde un tratamento máis profundo, e antes de mencionar algunhas das ideas que a súa lectura achega, vaia por diante que non é obxectivo desta recensión referirnos ás numerosas cuestións que destacan ao longo da obra, e iso porque o noso comentario, seguro que incompleto, non faría xustiza ao contido deste libro. Con 
todo, si nos gustaría pór de relevo algúns dos aspectos que, por diversas razóns, consideramos importantes

Na primeira parte - Resolución xudicial e extraxurisdicional de conflitos- inclúense catro estudos. O primeiro deles titúlase "La tutela de los derechos y libertades por los defensores del pueblo: del límite que representa la función jurisdiccional a la ampliación de las funciones mediadoras de los defensores", cuxa autora é a profesora González Moreno. Este traballo enmárcase no contexto máis xeral do cambio de paradigma na evolución do proceso contencioso-administrativo como mecanismo clásico de control da Administración. Este cambio determínase por dous planos que perfilan unha intensa transformación das relacións entre os cidadáns e os poderes públicos, caracterizado pola crecente demanda de participación cidadá nos procesos de toma de decisións públicas: por un lado, polas exixencias de transparencia na actividade dos responsables públicos, especialmente das administracións, as institucións e as entidades de dereito público, e, por outro lado, por unha visión máis depurada acerca das garantías dos dereitos dos cidadáns que deriva do deber de boa administración.

Os dous vectores referidos ao cambio de paradigma, a xuízo da autora, beneficiaron o impulso da mediación administrativa como un medio para resolver controversias. Por tal motivo, analízase esta institución co fin de plasmar as súas virtualidades. Distínguese non só a mediación en vía administrativa, senón tamén a que se leva a cabo de forma intraprocesual en virtude do artigo 77 da Lei 29/1998, do 13 de xullo, reguladora da xurisdición contencioso-administrativa.

A este respecto, cabe destacar a maior presenza que vén adquirindo a mediación no dereito administrativo, o que suscita un crecente interese polos operadores xurídicos, tanto no marco do dereito material pacífico como no do dereito procesual litixioso. $\mathrm{E}$ iso porque a mediación pode desenvolver un papel moi relevante no marco da concertación e o acordo, co fin de modernizar as estruturas administrativas, reducindo así o nivel de conflitividade.

Por último, abórdanse as funcións mediadoras que asumen os defensores do pobo no marco da tutela dos dereitos e liberdades que teñen encomendada. E, neste sentido, a experiencia da autora como coordinadora xeral do Valedor do Pobo, sen dúbida, engade á sólida fundamentación dogmática do estudo un profundo coñecemento especializado no funcionamento deste tipo de institucións.

O segundo traballo do libro, titulado "Arbitraje y conciliación en los Tribunales europeos", é elaborado polo maxistrado José Luis Gil Ibáñez. O autor proxecta a súa experiencia profesional nun estudo sobre a relación entre os tribunais da Unión Europea e os medios alternativos de resolución de conflitos. O seu fundamento reside en que, unha vez esgotada a vía pacífica para a solución das controversias, se pode acudir á vía xudicial ou a outras formas alternativas, como a arbitraxe, ademais de contar coa conciliación e a mediación.

Para iso, en primeiro lugar, aborda o tratamento que a arbitraxe recibe na xurisprudencia dos tribunais comunitarios, posto que os laudos dos árbitros poden suxeitarse ao seu control. E, en segundo lugar, analiza a conciliación xudicial nos procesos tramitados ante esta xurisdición e faino distinguindo a conciliación xudicial 
e a extraxudicial, por unha banda, e reflexionando acerca das funcións de conciliación que poden desenvolver os propios tribunais europeos, por outra. A este respecto, cabe distinguir entre os tres tribunais da Unión -Tribunal de Xustiza, Tribunal de Primeira Instancia e Tribunal da Función Pública-, xa que as posibilidades que presenta neles a conciliación xudicial son diferentes, debido á natureza tamén diversa dos procesos que se ventilan ante cada un.

Ao fío deste traballo, e como complemento do anterior, Alejandro González-Varas Ibáñez analiza, en "La resolución extrajurisdiccional de conflictos en el ámbito del Consejo de Europa", a utilización dos medios alternativos de resolución de conflitos no marco da outra xurisdición europea, isto é, a do Tribunal Europeo de Dereitos Humanos. A base deste estudo reside en que este tribunal experimentou nos últimos tempos un notable incremento dos asuntos que se lle someten, coa conseguinte necesidade de fomentar os medios alternativos ao proceso dirixida a reconducir a situación.

Por iso, o autor, partindo das últimas reformas experimentadas pola regulación do tribunal, examina a utilización dos acordos amigables, como forma de resolver extraxudicialmente o proceso, e os compromisos unilaterais asumidos polos Estados, así como as funcións que asume neste ámbito o Comisionado Europeo de Dereitos Humanos, como institución de carácter non xurisdicional, independente e imparcial, cuxa función consiste no desenvolvemento da educación e o respecto dos dereitos humanos.

A primeira parte do libro péchase cun traballo do profesor Mantecón acerca de "Los medios alternativos al proceso en el ordenamiento canónico". En efecto, pretende analizar superficialmente os medios alternativos ao proceso como forma de solucionar as controversias intersubxectivas que xorden no ordenamento canónico.

o punto de partida nestes casos é diferente. Aínda que os tribunais canónicos non están en absoluto colapsados, o certo é que a propia natureza do dereito canónico fai que o recurso aos medios alternativos ao proceso se converta nun imperativo moral. É dicir, neste caso o recurso a tales medios non só responde a razóns de eficacia xurídica, senón tamén a exixencias pastorais relacionadas coa salus animarum e á lei superior da caridade.

Por todo isto, o profesor Mantecón analiza, por un lado, a posibilidade de que o xuíz induza as partes a buscar a súa reconciliación, para que, de mutuo acordo, solucionen o conflito e desapareza así a necesidade de recorrer a un proceso xudicial, e, por outro, na medida en que esta opción non sexa factible, a posibilidade de acudir á transacción ou á arbitraxe.

Noutra orde de cousas, o profesor Canosa Usera comeza a segunda parte do libro cun estudo, - "Las relaciones entre el Tribunal Constitucional y el Tribunal Supremo. Problemas y soluciones"-, sobre unha das cuestións transcendentais do sistema xurisdicional español, "hoxe dificultosamente acougada", tal como sinalan os coordinadores, como son as relacións entre o Tribunal Constitucional e o Tribunal Supremo.

Resulta indiscutible que o Tribunal Constitucional ten un gran poder e, ademais, as súas decisións non poden ser revisadas por ningún outro tribunal nin nacional nin 
estranxeiro. Non resulta estraño, entón, que deba administrar o seu esencial labor para o mantemento do Estado constitucional con especial coidado e prudencia. Esta prudencia debe canalizarse a través dunha coidada e detallada fundamentación que permita comprender as súas decisións.

A este respecto, o autor enmarca a relación entre estes tribunais no seu contexto dogmático, explicando o modelo kelseniano de control de constitucionalidade concentrado e as deformacións que experimentou na súa aplicación práctica por influencia do modelo de control de constitucionalidade difuso. Así mesmo, identifica o problema básico que deriva da combinación de ambos os dous modelos e que, no noso país, orixinou a polémica que nos ocupa: a intervención do Tribunal Constitucional na interpretación da lexislación ordinaria, co conseguinte cuestionamento da posición do Tribunal Supremo, pola vía das sentenzas dos recursos de amparo e da excesiva utilización das sentenzas interpretativas nos procesos de inconstitucionalidade sobre normas con rango de lei. Ante esta situación, o profesor Canosa Usera valora posibles solucións, como a restrición aínda máis do acceso ao recurso de amparo ou a imposición de límites legais á posibilidade de que o Tribunal Constitucional dite sentenzas interpretativas.

Deseguido, atopamos un traballo sobre outra das tendencias de maior actualidade na evolución da Administración de xustiza: a introdución das técnicas electrónicas, tanto dixitais como telemáticas, no proceso. A profesora Iglesias Canle introdúcenos neste contexto a través da experiencia italiana co estudo titulado "El expediente digital y el proceso civil telemático en Italia", xa que o coñecemento das experiencias comparadas pode axudar a anticipar e previr as dificultades que a introdución das técnicas electrónicas presenta nun ámbito como este.

A autora toma como punto de partida a adopción dun novo modelo tecnolóxico na xustiza italiana, que consiste esencialmente na implantación do proceso civil telemático (PCT), entendendo por el a xestión integral e integrada da documentación producida no ámbito do calquera procedemento contencioso civil en forma dixital ou telemática. Ao seu través permítese a transmisión de comunicacións e notificacións, o depósito dos actos na secretaría, a constitución do xuízo e a inscrición telemática, así como a consulta do estado do procedemento, dos rexistros da secretaría, dos autos e da xurisprudencia por vía telemática, e, por conseguinte, posibilítase unha significativa redución dos tempos procesuais que sempre caracterizaron en negativo o sistema xudicial italiano.

Así, analízanse as características técnicas e o réxime xurídico que se aplican en Italia, tanto á dixitalización do expediente procesual civil como á incorporación da telemática ás relacións entre os operadores xurídicos que participan no proceso, pois con iso preténdese lograr a eficiencia da xustiza.

De igual modo, na parte final do seu traballo tamén se expoñen datos estatísticos sobre os primeiros resultados da implantación do PCT en Milán, que achegan unha visión práctica imprescindible para contrastar coa realidade os bos propósitos de lexislador. 
O sétimo traballo incluído no libro permítenos entrever que a procura de vías alternativas ás vías procesuais oficiais para resolver os conflitos intersubxectivos vén de moi atrás no tempo e para iso a profesora Martín García, en "La episcopalis audientia y su reconocimiento por la legislación constantiniana", sitúanos no pasado da Administración de xustiza. A autora aborda a análise da xurisdición dos bispos nos primeiros anos do cristianismo sobre materias seculares, en concreto de carácter xurídico-privado, cando os litixios relativos a estas se producían entre cristiáns, aínda que co tempo se ampliou tamén aos non cristiáns.

O certo é que moito se debateu acerca da natureza xurídica da extensión da xurisdición episcopal a asuntos de carácter civil, que para a historia do dereito resulta de grande interese, xa que estes litixios se tiñan que resolver aplicando o dereito secular. En concreto, cuestionouse se a xurisdición episcopal en materia de dereito privado entre cristiáns tiña verdadeiramente carácter xurisdicional ou se, pola contra, se trataba dunha actividade arbitral, aínda que fose unha arbitraxe de tipo especial.

Todo iso evidencia o interese que a episcopalis audientia suscitou e segue suscitando entre os especialistas de diversas ramas da ciencia xurídica e que levou a autora a elixilo como obxecto do seu estudo.

Máis alá da mirada retrospectiva da profesora Martín García, coa achega que Luis Míguez Macho realiza ao libro - "Autotutela administrativa y tutela judicial efectiva: nuevas perspectivas para el proceso contencioso-administrativo"-, volvemos aos problemas actuais da Administración de xustiza en España, en concreto aos que suscita o control xurisdicional da actividade administrativa.

Así, en primeiro lugar, abórdase o privilexio da autotutela administrativa no ordenamento xurídico español, xa que a posición da Administración respecto á xustiza é absolutamente diferente á dos particulares. En palabras do profesor Míguez Macho, "mentres que para estes a regra xeral é a da heterotutela, é dicir, para crear, modificar, extinguir e realizar situacións xurídicas sen o consenso da outra parte necesitan acudir aos órganos xurisdicionais, salvo nos supostos rigorosamente excepcionais en que se admite a autotutela, para a Administración rexe a regra contraria: salvo previsión legal expresa en contra, esta crea, modifica, extingue e realiza situacións xurídicas unilateralmente, pola súa propia autoridade, sen necesidade de auxilio xudicial". Seguidamente, analízase o alcance da autotutela no ordenamento xurídico, así como as súas consecuencias para a tutela xudicial do administrado fronte ás actuacións da Administración suxeitas ao dereito administrativo.

Por outra banda, trátanse as principais novidades en materia de control xurisdicional da actuación administrativa introducidas pola Lei 29/1998, do 13 de xullo, reguladora da xurisdición contencioso-administrativa, e a súa aplicación xurisprudencial. Entre elas, cabe destacar as seguintes: o recurso contra a inactividade material e a vía de feito; o novo réxime de tutela cautelar; os xulgados do contencioso-administrativo e o procedemento abreviado; e o novo réxime de execución de sentenzas.

Por último, maniféstanse as novas perspectivas que cabe amparar para a relación entre autotutela administrativa e tutela do administrado. Por un lado, analizaranse os aspectos novidosos producidos respecto ao tema da contratación pública, e que 
indican as preferencias que deberían xeneralizarse no futuro: isto é, a creación dun recurso administrativo especial de natureza potestativa, cuxo coñecemento e resolución se encomenda a órganos dotados de independencia funcional, e unha regulación da tutela cautelar máis áxil que a ordinaria, cando se pretenda reclamar o pagamento de cantidades líquidas de diñeiro á Administración. E, por outro lado, expóñense as posibilidades de introdución dos procedementos alternativos de resolución de conflitos no eido administrativo, especialmente a mediación, como vía para desviar parte dos litixios do ámbito xurisdicional a outras formas voluntarias de solucionalos. E iso debido a que tradicionalmente estas posibilidades se atopaban moi constrinxidas pola forte vantaxe procesual que o principio de autotutela administrativa lle outorga á Administración pública.

A continuación, abórdase unha cuestión que xa aparecera en traballos anteriores deste libro; referímonos á relación no plano procesual entre os ordenamentos confesionais e os seculares. Neste caso, Montserrat Perales Agustí, nun extenso e documentado estudo titulado "Recepción de la jurisdicción confesional en el derecho secular: el reconocimiento de la jurisdicción rabínica", dálle un tratamento detallado para o caso da xurisdición rabínica.

Neste sentido, inclúese unha análise exhaustiva non só da evolución da relación da xurisdición rabínica coas xurisdicións seculares, desde a diáspora do pobo xudeu á actualidade, senón tamén dos enormes cambios que trouxo o Estado constitucional implantado polas revolucións liberais e a recepción actual do dereito relixioso xudeu, tanto no ordenamento xurídico do Estado de Israel como no doutras sociedades avanzadas de carácter multicultural. Máis alá de todo isto, resulta imposible aludir e explicar en profundidade todos e cada un dos contidos da cuestión abordada pola profesora Perales. Con todo, si é certo que as preguntas que a autora suxire acerca dos desafíos que esa recepción presenta confrontan o lector cos propios límites do Estado democrático de dereito e da súa elasticidade para dar apoio ás demandas multiculturais.

En último lugar, o maxistrado José Luis Requero Ibáñez pecha o libro cunha contribución acerca de "La crisis del actual modelo de gobierno judicial". En realidade, considérase que ninguén mellor que un maxistrado que foi vogal do Consello e, polo tanto, experimentou desde dentro o funcionamento da institución para analizar este tema.

Este estudo parte do nada satisfactorio balance do sistema constitucional de goberno da xustiza. Por iso, retrotráese ao pasado, co fin de recordar como se chegou ata esa situación, como o modelo constitucional de goberno do poder xudicial foi esquecido, en especial a partir da Lei orgánica 6/1985, do 1 de xullo, do poder xudicial. O autor considera que ese esquecemento é consecuencia doutro esquecemento: o dos cidadáns con dereito a un sistema xudicial independente, forte e eficaz. Sinxelamente, analizando as vicisitudes dos últimos vinte e sete anos, chégase á conclusión de que a actitude do poder político cara á xustiza foi o interese por controlala e desactivala no que poida afectarlle e o desinterese por esa xustiza de prestixio, independente, forte e eficaz. Neste sentido, exponse a existencia dunha "tormenta perfecta", xa que se 
produciu unha crise de lexitimación sen precedentes do réxime de goberno do poder xudicial, crise que arrastrou as propias asociacións de xuíces, e cuxo detonante foi o caso "Mari Luz Cortés", un suceso que impactou na opinión pública. O certo é que o poder político desde o primeiro momento eludiu toda responsabilidade e procurou que recaese sobre o xuíz e, por reflexo, sobre a secretaria xudicial.

Suposto isto, abórdase o que pode ser o inmediato futuro, futuro presidido pola expresa declaración do actual Goberno de volver ao modelo de goberno xudicial nacido da Constitución de 1978, o que se concreta no sistema de elección dos vogais xudiciais do Consello Xeral do Poder Xudicial. Así mesmo, formúlase se este Consello Xeral debe reformarse para ir a un órgano reducido ou segue mantendo o esquema actual de organización. E finalmente exponse un exemplo referido ás competencias en materia informática, en concreto acerca do expediente dixital.

De todo o apuntado ata o momento, constatamos que o tema da modernización da Administración de xustiza non perde nunca actualidade, polo que está máis que xustificado este conxunto de contribucións tan meditadas e fundamentadas como as presentes. De aí despréndese o enorme interese da obra colectiva Resolución judicial y extrajurisdiccional de conflictos en el proceso de modernización de la Administración de Justicia. O seu gran valor estriba no enriquecemento que achega ás propias posicións o intercambio de opinións con investigadores pertencentes a diferentes áreas de coñecemento do dereito público, que abren novas perspectivas á reflexión acerca dos problemas que formula o actual proceso de modernización da Administración de xustiza. Por todo iso, recoméndase a atenta lectura desta obra colectiva obxecto de recensión a todas e a todos os xuristas interesados en afondar no coñecemento do dereito administrativo, pois sen dúbida atopámonos ante un traballo útil, tanto para os teóricos como para os prácticos do proceso contencioso-administrativo. 
